\title{
Death or taxes? An examination of recent changes in tobacco taxation policy in Canada
}

\author{
MICHAEL DE GOODYEAR BMedSc MB BS FRACP FRCPC FACP \\ Department of Medicine, Hamilton Regional Cancer Centre, McMaster University, \\ Hamilton, Ontario
}

MDE GOODYEAR. Death or taxes? An examination of recent changes in tobacco taxation policy in Canada. Can Respir J 1994;1(2):95-103.

Manipulation of the price of tobacco products has proven to be one of the most effective tools in tobacco control. However, a strategy relying predominantly on tampering with free-market conditions by raising prices independently of the quantity available is unlikely to be successful over the long term, unless balanced by equal efforts to reduce demand. Canada has a number of unique factors which combined to create a contraband market that eventually led to political pressure for action at a national level. Although presented with a number of policy alternatives, the federal government based its strategy on reducing tobacco taxes to compete with the contraband product. Provision of an effective comprehensive national strategy to combat tobacco has yet to be realized. Econometric models predict significant changes in consumption from drastic tax reductions that effectively halved the retail price in a large part of Canada. The medical profession and public health authorities will need to combat these effects, not only by working for restoration of fiscal pressures but also for sweeping measures to restrict overall demand if increases in long term morbidity and mortality are to be prevented.

Key Words: Canadian government, Smoking, Smuggling, Taxes, Tobacco

\section{La mort ou les taxes ? Un examen des change- ments récents dans la politique de taxation du tabac au Canada}

RÉSUMÉ : La manipulation du prix des produits du tabac constitue le moyen le plus efficace pour contrôler l'usage du tabac. Cependant, une stratégie qui dépend principalement de la falsification des règles de l'économie de marché et qui est basée sur une augmentation des prix indépendante de l'offre est probablement vouée à l'échec à long terme, à moins que cette stratégie ne soit contrebalancée par une volonté équivalente de réduire la demande. Le Canada a un nombre de facteurs uniques dont l'association a créé un marché de contrebande, lequel a finalement causé des pressions politiques pour qu'une action ait lieu à l'échelle nationale. Bien qu'un certain nombre de solutions politiques aient été présentées au gouvernement fédéral, ce dernier a opté pour une réduction des taxes sur le tabac pour faire concurrence aux produits de contrebande. Il reste à élaborer une stratégie globale de lutte contre le tabac. Des modèles économétriques prédisent des changements significatifs de la consommation dûs à la réduction massive des taxes qui a, en effet, fait chuter les prix de détail de moitié dans une grande partie du Canada. La profession médicale et les responsables de la santé publique devront lutter contre ces effets, non seulement en travaillant au rétablissement des pressions fiscales, mais aussi par des mesures radicales pour limiter la demande en général si l'on veut réduire la mortalité et la morbidité à long terme. 
B ENJAMIN FRANKLIN ONCE MUSED "IN THIS WORLD nothing can be said to be certain, except death and taxes" (1) in one of the world's best known quotations. However, Franklin does not seem to have considered that the two certainties might be mutually exclusive. "But for some people, the latter can help to delay the former", added Norman Lamont, Chancellor of the UK Exchequer 200 years later (2).

Taxation has been part of the usage of tobacco in the western hemisphere ever since its introduction there, when James I (1603-1625) raised the duty on Virginia tobacco by $4000 \%$ in 1624 (3). Taxes were imposed by both the Imperial as well as colonial governments, and played no small part in the war of American independence. With the advent of Confederation in Canada, the role of tax collector was transferred from the provinces to the Dominion Inland Revenue Act 1867 (4). At that time excise duties on tobacco were continued at the preconfederation level (5) of $10 \AA / \mathrm{lb}(22 \mathrm{c} / \mathrm{kg})$, and with only occasional fluctuations, remained at this rate until 1918. Although the exigencies of war identified tobacco as a revenue-raising possibility, the postwar period saw little change in Canadian tobacco taxes in real terms (adjusted for inflation), even with the reentry of the provinces into the field. Ontario, for instance, had introduced its own Tobacco Tax Act (6) in 1965. Indeed, between 1940 and 1981 cigarette taxes declined by $64 \%$ in real terms (Figure 1). With the advent of indexation of commodity taxation in the 1981 federal budget, the modern era of steadily rising taxes was introduced, so that by 1991 federal taxes had increased $251 \%$ from their lowest point in 1981. to stand at $127 \%$ of 1940 levels.

Despite these recent changes it is important to realize that, when tobacco prices are examined relative to shifts in other prices and incomes, the effective price (adjusted for both disposable income and inflation) has remained less than it was in the postwar period (Figures 2,3). Furthermore, while high taxation rates in Canada were frequently blamed for the development of black market sales, Canada's rates of taxation were comparable to those of the other industrialized nations (7), with the exception of the United States, which is an outlier (Figure 4).

\section{TAXATION AS HEALTHY PUBLIC POLICY}

Despite the fact that tobacco and other 'sin' taxes generate a good deal of public cynicism in Canada and elsewhere, and while they undoubtedly generate useful revenue for governments, this amount is relatively small by budgetary standards, being dwarfed by the total economic costs to society of tobacco usage. In 1983 tobacco taxes represented $2.4 \%$ of total government revenues in Canada and $1.9 \%$ in the United States. Economic costs of tobacco use, direct and indirect, amount to nearly three times the revenue generated. In 1991, direct revenue to the Ontario government from tobacco was $\$ 1.1$ billion compared with economic costs of $\$ 3.1$ billion (8). The 1980s saw a gradual realization on the part of government that taxation could be used as a policy tool for adjusting consumption of unhealthy or environmentally un-

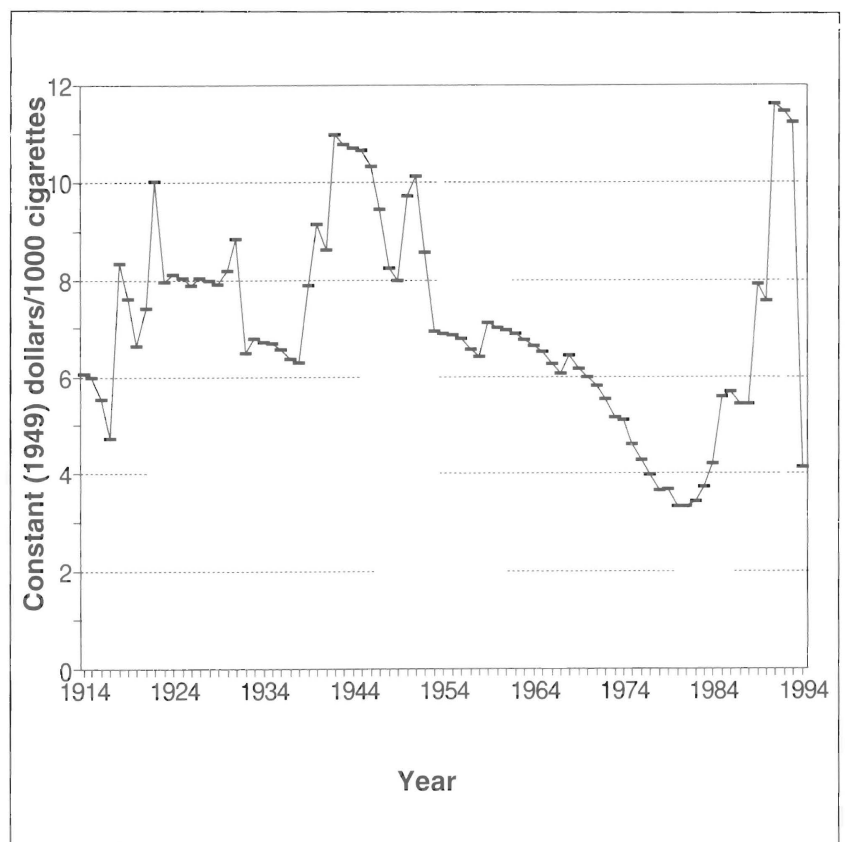

Figure 1) Canadian Federal cigarette taxes 1914 to 1994 expressed in constant 1949 dollars to take changes in the consumer price index into account. This is often described as expressing prices or costs in real terms. Note the rises associated with each of the two world wars, the attempt by the Saint-Laurent government to increase taxes by $\$ 1.50 / 1000$ cigarettes in 1951 , and the rapid retreat in the face of smuggling, the steady erosion in the postwar decades, the sharp rises of the 1980s and the steep cut in 1994. Actual taxes were \$3 in 1914, \$8 in 1949, \$11.50 in 1951, \$12.10 in 1980, \$79.25 in 1993 and \$29.25 (Quebec) in 1994. (Source: Statistics Canada)

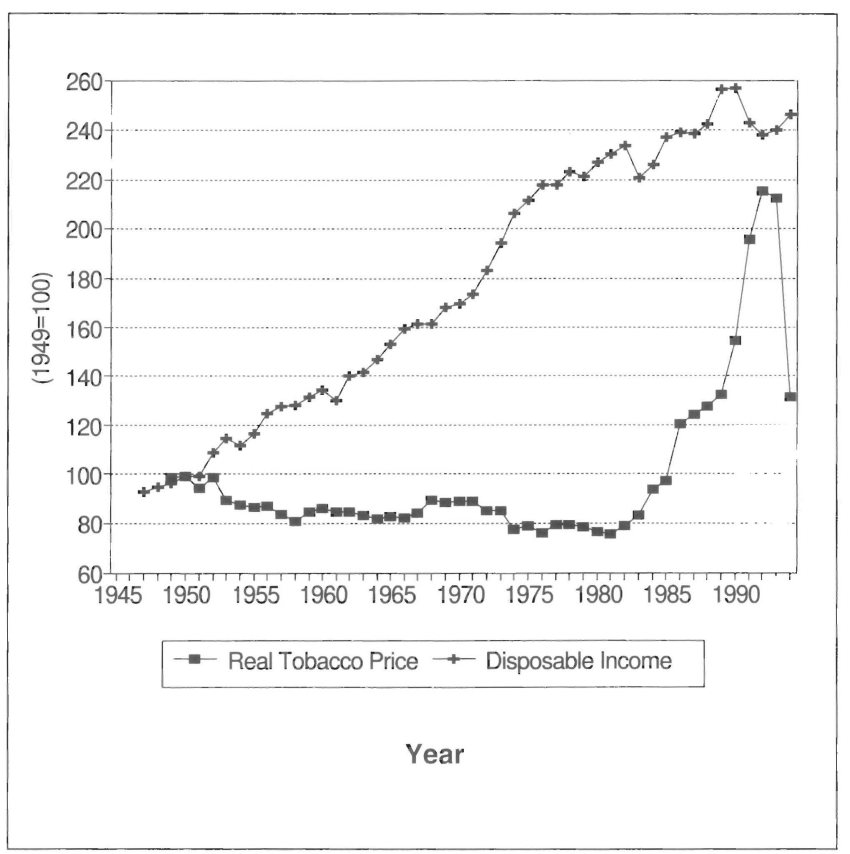

Figure 2) Real tobacco price index and real personal disposable income, age 15 and over for Canada 1947 to 1994. All values are adjusted for consumer price index and standardized to a base of $1949=100.1949$ is the first year for which separate tobacco price indexes are available. 1993 and 1994 figures are estimates based on available data up to the third quarter of 1993 (income) and the first quarter of 1994 (price). (Source: Statistics Canada) 


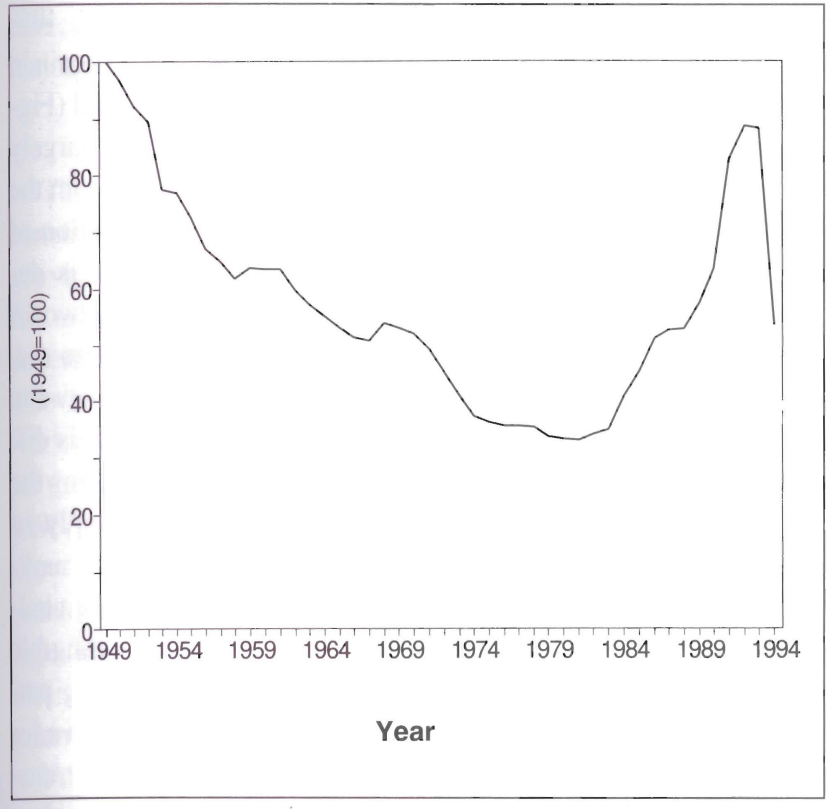

Figure 3) Effective price of tobacco products, Canada 1949 to 1994, calculated to a base index of 1949=100. The effective price is the real price adjusted for personal disposable income. The reciprocal of effective price is affordability. (Source: Statistics Canada)

friendly products (9), and successive finance ministers turned to health economics to justify altering the taxation base (1013). More recently many jurisdictions have recognized tobacco taxation as a means of financing health care. While the United States administration's proposal for taxation as part of health care reform is a novel federal initiative, several of the states have such a scheme in place already (14).

\section{Taxes, price and demand}

The law of downward-sloping demand, namely, that demand for a commodity declines as its price increases, is a fundamental economic concept (15). The relationship between the change in price and the resulting change in demand for a commodity is known as its price elasticity of demand and is expressed as the ratio of the percentage change in demand to the percentage change in price. Not surprisingly this law holds for tobacco products as it does for other consumer items. Indeed, there is now a substantial body of literature examining tobacco elasticity in different settings, including the effects within different groups such as age and sex, and the effects on total consumption of the product as well as the quantity used per smoker and the total prevalence of smoking. Both short and long term effects of price changes can be modelled (16). Elasticity for the adult population is of the order of -0.4 , eg, a $10 \%$ increase in price would be expected to result in a $4 \%$ decline in demand. For the adolescent population, this effect is larger, about-1.4, implying that this group is more price sensitive (17-19). In general these predictive models have stood up well to analysis of actual change (20). In Canada, where taxation represented 69\% of the retail price until this year, fiscal policy presented a readily available tool for controlling price and hence consumption.

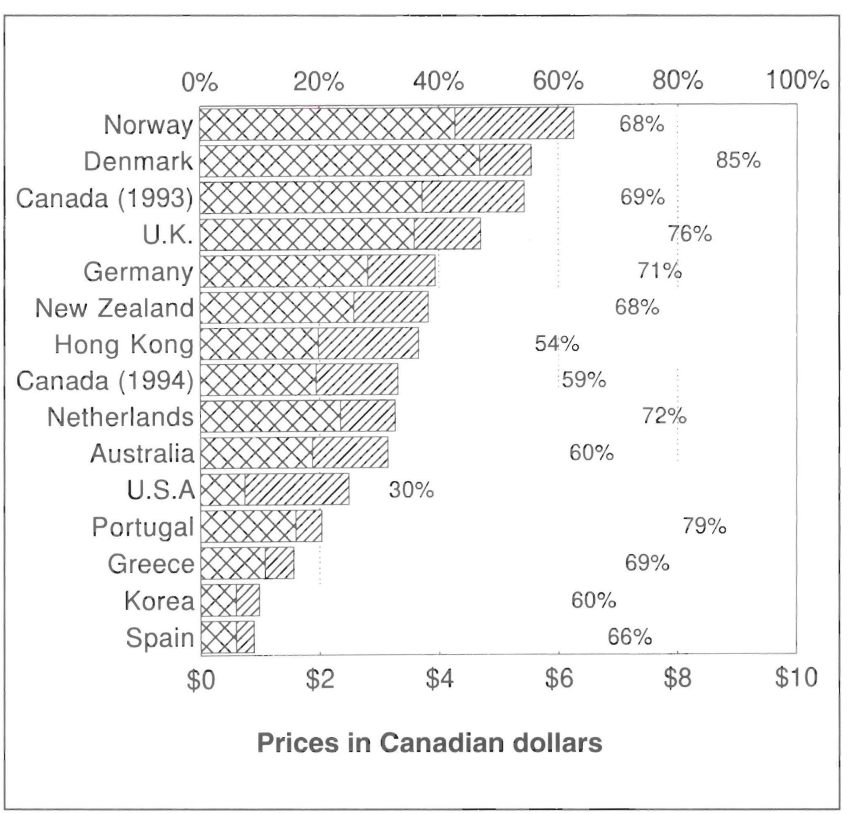

Figure 4) Total taxes and retail prices for selected countries 1993 to 1994. The length of the bar represents the retail price in Canadian dollars (lower horizontal axis), with the tax component indicated to the left in the cross-hatched portion. Taxes as a percentage of the retail price are plotted as figures to the right of each bar (upper horizontal axis). Canadian data represent the average for each province after weighting by the size of the population over 15 years of age. Prices are not directly comparable among countries other than for purposes of smuggling, since they do not take into account differences in cost of living and income. Note that although the United States does not have the lowest taxes, it has the lowest contribution to retail price from taxation. (Source: Non-Smokers' Rights Association)

\section{Taxes and health outcomes}

Based on the available mortality data for tobacco, trends can be projected for the above estimates of shifts in demand $(21,22)$. Due to the latency period of 20 to 30 years $(23)$ between exposure and outcome, the full effect of these changes may not be seen for decades (Figure 5). The majority of such predictions are based on averting premature death, for which somewhat more reliable estimates of the risk from a given exposure are available. But since many years of illhealth precede tobacco-induced mortality, the effects on total morbidity should become apparent much earlier.

\section{Taxation as part of comprehensive control policy}

No other strategy can be demonstrated to have such a close relationship to consumption as taxation, yet any program that relied on a single strategy is unlikely to succeed in controlling such a complex social phenomenon, and is vulnerable to compensating social forces (24). In substance abuse there is a critical need to balance control of supply with that of demand. Prohibition of alcohol in North America in the first half of this century is one of the best known examples of the limitations of control policy based on restricting access alone. Consumption was decreased but at an unanticipated social price in terms of law and order. Increasing taxes without equal measures to reduce the inherent demand for the product 


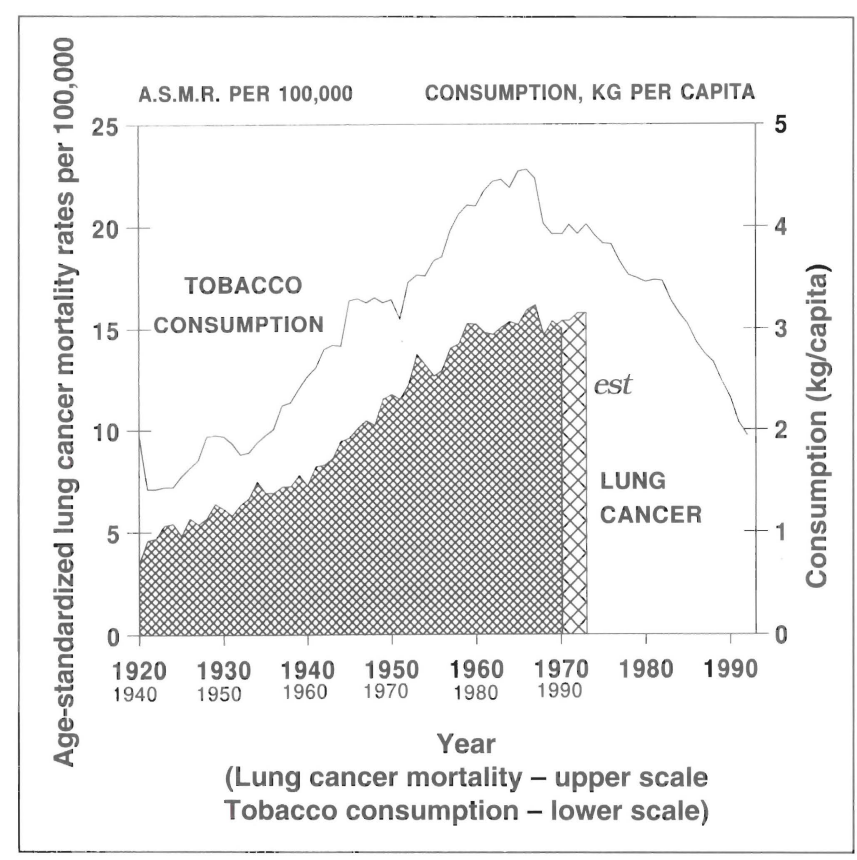

Figure 5) Tobacco consumption in Canada 1920 to 1992, plotted against age standardized lung cancer mortality rates 1940 to 1993, for ages 25 to 54 years, adjusted to the world population. Lung cancer mortality is plotted on a time frame that has been shifted back 20 years to reflect exposure then. The coarse cross-hatching (est) indicates use of projected data for cancer mortality for 1990 to 1993. (Source: Health and Welfare Canada)

creates the risk of unmitigated demand finding new ways to develop access.

As Becker and colleagues (19) have pointed out, the econometric analysis of supply and demand of addictive products such as tobacco requires rather more complex modelling, which they have called a model of rational addiction. This takes into account both past and future consumption, incorporating the effects of addictive behaviour such as tolerance, withdrawal and reinforcement. While taxation, by changing price, simply moves the addicted population's behaviour along the traditional demand curve of price versus quantity demanded, the inherent demand or craving is unaltered, creating scope for new market strategies. By contrast, nonprice policies, such as eliminating advertising, shift the demand curve itself. In the first case the relationship between the quantity demanded at any given price remains fixed, in the second the quantity demanded at a given price decreases. Both policies are examples of demand-side interventions in conventional macroeconomic terms.

\section{TOBACCO SMUGGLING: MYTHS AND REALITIES The growth of contraband}

While tobacco smuggling is as old as taxation itself, there has rarely been seen anything on the scale witnessed in Canada in 1993. Industry sources have consistently maintained that high taxation is a burden on the community, discriminating against a visible minority and creating crime. Similar arguments were heard during the campaign to raise California's taxes in 1989. Price differentials exist across many national borders. For instance, retail prices are $40 \%$ higher in Denmark than in Germany and 13\% higher again in Norway, without significant problems with contraband (Figure 4). The Canadian problem is unique in that it is largely composed of the smuggling of Canadian cigarettes from the United States back into Canada, rather than importation of cheaper cigarettes from a neighbouring country. This depends on a number of key ingredients: distribution networks set up between Canadian manufacturers and American distributors that crossed traditional competitive lines between the transnational conglomerates; a long border which is difficult to police; the presence of Native reserves straddling the international border together with a traditional supply of tax-free tobacco; the lack of adequate tax-paid product markings; and an ineffectual government response once the challenge to sovereignty was recognized. Other less tangible factors may have also played a role, such as changing patterns of power within the Native community and the drive for self-determination. All these factors allowed the ready transfer of tobacco, on which Canadian duty had not been paid, to distribution points along the United States-Canada border and its easy movement through reserves back into Canada where it supplied a network of illicit outlets. Historically about $3 \%$ of Canadian tobacco crossed into the United States, where there was very little of a legitimate market. Similarly, imported tobacco constituted less than $1 \%$ of the Canadian market. These exports supplied Canadians living or travelling in the United States, and the duty-free market which enjoyed a boom during the peak of cross-border shopping.

During the late 1980s a new phenomenon became apparent: the increasing discrepancy between domestic production and domestic sales, with the balance appearing as exports to the United States and the tiny islands of St Pierre et Miquelon, off the Newfoundland coast. This early trend rapidly grew until, by the end of $1993,38 \%$ of production was leaving the country, a large proportion of which was being recycled across the border (25).

\section{The 1992 export tax}

A dramatic demonstration of the extent of the problem became apparent on February 12, 1992 when the federal government imposed an export tax of $\$ 8$ per carton of 200 cigarettes, narrowing the price between domestic and exported Canadian tobacco. In the course of the eight weeks that the tax was in place, not only did exports return to normal, but domestic sales rose sharply, demonstrating the presence of an alternative source of supply. Unfortunately the Federal government caved in to rather dubious tobacco industry threats to move their production out of Canada, and revoked the tax on April 8. Consequently exports continued to grow and legitimate domestic sales to fall.

While it is difficult to quantify the volumes sold and prices paid for black market cigarettes, there is little doubt that the increasing availability of cheaper cigarettes, particularly in Quebec (where smoking prevalence is the second highest in Canada as well as being closest to the main source of tobacco reentry to Canada), effectively blunted the rapid decrease in 
tobacco consumption during the previous decade. Thus, one major objective of the tobacco industry was achieved.

\section{THE RETREAT FROM TAXATION}

The 1994 taxation crisis that plunged the country into constitutional and fiscal turmoil arose more from a lack of activity than any particular event. Overreliance on taxation for tobacco control, watered down legislation controlling advertising and environmental tobacco smoke, failure to provide either adequate enforcement of border controls or to work effectively with American authorities, reluctance to act on the Native question following the Oka confrontation in 1990, lack of jurisdiction of provincial police forces, and the show of weakness over the export tax all contributed to the problem. Meanwhile federal authorities appeared to be turning a blind eye to the problem as it continued to grow, even when industry executives boasted about the profits to be made (26).

Finally a new government in Ottawa searching for initiatives, relentless pressures from the Bloc Québécois and a new premier in Quebec about to face an election against a strong separatist movement, forced the hand of the Chrétien government to show its mettle in the face of provocation. The industry was orchestrating illegal sales of tax-free tobacco, and even the Catholic church became involved with what one priest called "illegal but not immoral" (27) tax evasion. Paul Martin, the Finance Minister, was in a difficult position, committed to reducing the deficit, but also a former tobacco industry director who had supported the industry's position on the export tax in 1992. The Prime Minister made the issue a personal commitment and set about winning over the caucus while the medical and health community laid siege. Eventually a package of measures was produced which pleased nobody, but which, according to data on the disposition of tobacco products for the period from February to April of this year, appears to have produced a partial reversal of the contraband issue for now.

\section{The Chrétien package}

On February 8, 1994 Prime Minister Jean Chrétien outlined his four-point solution to tobacco smuggling in the House of Commons. Essentially it consisted of tax reductions and a package of three other measures to give the appearance of being comprehensive. These were enforcement, new taxes, and improved tobacco control. In reality there were immediate initiatives, and a series of planned measures to win back credibility from the health community. Immediate measures consisted of a reduction in federal taxes from the 1991 level of $\$ 79.25$ per 1000 cigarettes to $\$ 54.25$ per 1000 across the country. This $\$ 25$ reduction is more conveniently expressed as a $\$ 5$ reduction per carton of 200 cigarettes from $\$ 15.85$ to $\$ 10.85$. There was a promise to match any reductions in tax by the provincial governments with further cuts in the federal tax, to a maximum of $\$ 10$ per carton, the latter being effective immediately in Quebec. After sales taxes are taken into account, the $\$ 10$ per carton reduction in federal tax and the $\$ 11$ per carton reduction in Quebec taxes was equivalent to a 52\% drop in the retail price by $\$ 24.27$ from $\$ 47$ to $\$ 22.73$. Neighbouring New Brunswick quickly fell into step with a $\$ 7$ cut, as did Prince Edward Island (\$9.20) and Ontario (\$9.60). Nova Scotia was the most recent province to cave in to smuggling across its border with New Brunswick with a cut of $\$ 7$ on April 13. Thus tax cuts in five of the 10 provinces are providing tobacco to $69 \%$ of the population at prices varying between $48 \%$ and $67 \%$ of their former level.

The other immediate measures were supposed to be a new commitment by the police (RCMP) and Revenue Canada to crack down on smuggling (resources for which have not as yet materialized), a reimposition of the export tax (with exemption for 'historic markets'), and a three-year $40 \%$ surtax on tobacco manufacturers' income tax. The latter is expected to yield $\$ 200$ million over the time it remains in force, and is promised for health promotion. Details of this so-called Tobacco Demand Reduction Strategy are still awaited.

Less tangible were the plans to reduce smoking in Canada. Many of the steps that were announced were already in place or had been planned a long time ago. The Liberal government suddenly proclaimed the Tobacco Sales to Young Persons Act 1993 (28), which had been passed by the previous Conservative government, thereby abrogating the public discussion period on the draft regulations. There is no evidence that compliance is any better than it was for the Act it replaced, the Tobacco Restraint Act 1908 (29). The government also announced new health warnings on packages despite the fact that they had been gazetted the previous August. Increased spending on advertising to discourage children from smoking was even less convincing, given the reaction of the target group to previous efforts (30). Announcements of plans (still to be implemented) to prohibit sales of cigarettes in pack sizes of fewer than 20 , because these cheaper packs were favoured by children, were also unconvincing since now even full-size packs cost less than the so-called 'kiddiepacks' did before the tax changes. The proposal to ask the House of Commons Health Committee to look at plain packaging of tobacco products was more promising, and these hearings have now been completed. However, a committee agenda is still a far cry from announcing any actual action on the issue.

From a policy analysis perspective this package was a law and order and economic strategy (31), marking a departure from the emerging viewpoint of seeing tobacco as primarily a health issue with economic implications.

\section{MEASURING THE EFFECTS}

There are many reasons why an exact measurement of the outcome is very difficult to achieve. The recent changes in the tobacco taxation structure have been an evolving process as international tobacco smuggling was progressively replaced by interprovincial smuggling. What further changes will occur, and what will happen to the remaining five provinces in which only the federal (and the resultant sales) tax changes apply, remains to be seen. These provinces are monitoring revenue changes very carefully, as a measure of the extent of illegal sales and the financial impact on the retail 
sector, which constitutes a significant political pressure group. The tobacco industry's position within the Retail Council of Canada can be expected to be playing a part in this process as well. What is clear is that, for the first time, major differences in the retail price of a large-scale commodity exist interprovincially. Since smuggling was not uniform across Canada, the implications for each province will be driven by two major factors, the extent of black market sales before the tax changes, and the extent of the corrective changes introduced. While the latter can be quantified precisely, the former can only be roughly estimated, but the net effect is the change in the aggregate price of the commodity, legal and illegal. The aggregate effect has been to shift the problem from one region of Canada (predominantly Quebec), to the country as a whole, with a resulting deterioration in both interprovincial and federal-provincial relations. These effects will then have an impact on consumer behaviour as a result of price changes, and provincial and federal programs directly through revenue losses and indirectly through increased health care use if tobacco consumption increases. Ironically one of the targets of the revenue losses has been health care funding. This can be considered the corollary of the Clinton administration's proposed use of tobacco revenue to fund health care.

The next area of uncertainty relates to the fact that econometric models are developed from studying small incremental changes over time, and like all mathematical models require considerable caution when applied to making predictions based on observed change outside the range of values on which the models were constructed. Similarly the models have only been demonstrated to have predictive validity to date when applied to small changes, and elasticity itself may change along the demand curve, as a function of initial price. The combined effect of federal and provincial tax changes in February exceed any annual changes since Confederation. The enormous publicity surrounding these tax changes, the air of anarchy surrounding deliberate sales of tax-free cigarettes, and the festive atmosphere that accompanied the first legal sales of half-price cigarettes are all likely to have inflated elasticity and increased consumption.

Predictive models based purely on elasticity relationships assume a relatively uniform pricing structure so that there is only one source for a product. Contraband introduces a new source of competition, making the product available at very different prices within a single area, and leading to shifts between these legitimate and illegitimate compartments.

Finally there are certain correcting mechanisms within the economic and social framework, such that large scale changes are modified to prevent undue disruption and to preserve a degree of societal homeostasis.

\section{Methodology}

In providing advice to finance departments (32) on the potential implications of taxation changes, the following strategy has been used to provide the best estimates. Based on the age-dependant price elasticity described above, the population is partitioned into age strata. The most convenient partition is a dichotomous one, of ages 15 to 19 years and 20 and over. This isolates the important adolescent group where the greatest changes in tobacco usage occur and where the potential impact is greatest because of the likely chronic exposure and health outcomes over a potential lifetime.

From age-dependent tobacco usage prevalence surveys and census data the number of current users in each strata is determined. Given the existing price structure, a range of possible tax policy alternatives can be modelled. The resulting retail prices can then be calculated, and using estimated price elasticity and the changes in real price, the resulting change in demand (consumption) is determined. Similar calculations can be used to determine the expected change in participation (prevalence).

Given a lifetime risk of avoidable premature mortality from tobacco usage of about $25 \%$ for adults and $18 \%$ for adolescents, an estimate of the number of tobacco-related deaths avoided in each strata can be derived. Finally, the expected revenue implications for each alternative considered is derived by factoring in the expected change in consumption.

For instance in 1992 it was calculated that to leave federal taxes (which are not currently indexed) static would result in a net increase in premature deaths of 5470 over a lifetime and a net loss in revenues of $\$ 128$ million. This would occur by erosion of real prices from the then level of inflation, after taking anticipated changes in manufacturers' prices and a background decline in smoking prevalence from other factors into account. A table of expected revenue and premature deaths avoided was then constructed as a function of incremental tax changes. For the recommended 34\% change of $3 \phi / g$ or cigarette, it was predicted that sales would decline $8.5 \%$, and revenues increase by $\$ 1$ billion (23\%), while 600,000 smokers would leave the market and 6000 children would be prevented from entering the market, resulting in 150,000 premature deaths averted. Despite these recommendations no change in taxation occurred in 1992.

Clearly there are a lot of assumptions made in these estimates, and therefore the actual numbers should be treated with due caution.

\section{Calculating the damage}

Any calculations will have to take into account regional variance. Even within each region, determining the independent variable, change in average retail price in real terms is difficult. In February 1993, Robert Allan, a professor of economics at the University of British Columbia, published an analysis of the economic forces involved in the production and use of tobacco in Canada, and the impact of control policies on those forces (33). In February of this year, before the government announcements, Allan, now at Harvard, wrote a postscript examining the likely impact of reducing taxation (unpublished communication). Allan argues strongly that Quebec is in a unique situation. He estimates that in Quebec, which accounts for 30\% of tobacco consumption in Canada, only a third of this ( $10 \%$ of the national total) represents legal sales at full price. 
Under these circumstances conventional elasticity-based predictions can be expected to break down. Price decrements in the legal sector will be reflected in the share of the contraband market that they displace. Assuming the policy objectives are to displace contraband completely, price changes must be sufficient to provide for an increase in legal sales from the current one third to $100 \%$ of the market, a $200 \%$ increase. Given the approximately $50 \%$ reduction in price that occurred, it would require an elasticity of $+200 / 50$, or +4 , which is 10 times that usually observed. If the goals are not reached, and displacement of contraband is less than complete, estimates of elasticity need to be discounted. Thus a displacement of $10 \%$ of the contraband market, corresponding to a $20 \%$ increase in legitimate sales, would indicate an elasticity of only $20 / 50(0.4)$, the more usual level observed in a noncompetitive model.

The simplest (and most conservative) assumption to make for Quebec is that the price reductions achieved through taxation approximate the competitive price, and achieve the desired goal by displacing contraband. This would keep average prices approximately constant and hence not affect overall consumption. If these assumptions are incorrect, the bias in the estimates is likely to be in the direction of expanded legal sales from price reduction without displacing an equivalent volume of contraband, ie, a net increase in demand. In reality, in a competitive environment of this type, with very different channels of distribution, many factors other than altering the price of the legal product will influence the degree of displacement. In the first place the margins on contraband are likely to be reduced to attenuate the changed price differential, and maintain as much of the market share as possible, while the export tax is unlikely to work for those sources of tobacco that were being provided tax-free, such as to Native reserves. Other factors will include availability, supplier loyalty (especially if the contraband channels are also supplying other goods such as alcohol whose tax base was not altered), the perceived probability of being apprehended, risk-taking behaviour and a general aversion to paying taxes, no matter how low they may be.

Even if the goals of the policy were successful in this high smuggling area, the gains are more than offset by the undesirable consequences. The direct effects are twofold. Applying the federal reduction across the country, regardless of the level of contraband sales, would produce the expected expansion of demand. Next, huge price discounts in legal sales in Quebec created equally large price differentials across adjacent provincial boundaries, switching smuggling to an interprovincial basis, creating a whole new law and order problem and effectively lowering the average price in those provinces. The result has been a domino effect in our linear geography, whereby each province has been faced with a sudden increase in smuggling, and a choice between simply losing revenue, or going into competition with smuggling, reducing taxes, still losing the revenue and passing the problem on to the next province in line. The indirect effect has been a complete undermining of government programs to reduce tobacco consumption. There is a hidden message that somehow govern- ments are providing 'cheap smokes' as an acknowledgement of a mistaken policy in keeping tobacco prices high as a deterrent, and an implicit message that smokers are being vindicated and rewarded to compensate for previous injustices. The other indirect consequence is the precedent for similar handling of other commodities with high tax incidences and historical black market sources, such as alcohol.

At a very simple level, if a 50\% decrease in prices were applied across Canada, a 0.4 elasticity would predict a $20 \%$ increase in consumption. If this is applied outside the areas in which we would predict that legal sales may merely displace contraband, and which account for $30 \%$ of consumption, this increase should be discounted to $14 \%$. Using a prevalence base of six million smokers, of whom 500,000 are teenagers, and a differential in elasticity by age, Allen estimates an increased market of 665,000 adults and 175,000 teenagers, which can be translated into about 198,000 avoidable premature deaths. Applying a 50\% retail price decrement across the whole country is not a completely worst case scenario, considering that reductions of this order of magnitude already apply to $59 \%$ of the population outside of Quebec. Allen considers the plausible range of elasticity estimates to be 0.4 to 0.9 for adults and 1.0 to 1.4 for teenagers. Using the upper bound of the elasticity estimates, to provide a range of possible values, would increase consumption $32 \%$, expand the market by 1.89 million and contribute 455,000 avoidable deaths.

Taking an average of the population estimates, and a population-weighted average of the retail price reductions outside of Quebec (35\%), would yield 1.1 million more smokers (18\%) and 281,000 avoidable deaths, as a reasonable estimate of the damage to date.

\section{Calculating the cost}

Societal costs do not stop there, since increased tobacco consumption will result in increased health care costs. Taking a current estimate of $\$ 9.5$ billion in health care costs, the addition of an additional 18\% users would increase health care spending by $\$ 1.7$ billion.

At the same time overall government revenues are decreasing. There is no way governments, especially those in low smuggling areas, could benefit from this. Finance ministers have estimated their losses as $\$ 500$ million in Ontario (34), and \$93 million in Nova Scotia (35).

Allen estimates consumption at 43 billion cigarettes ( 215 million cartons). Of this, 172 million cartons (80\%) are legal and the remaining 43 million (20\%) are contraband. Again it is helpful to use the model of separate analyses for a high smuggling area (predominantly Quebec, eastern Ontario and parts of New Brunswick), and a low smuggling area elsewhere in Canada. Seventy per cent of total consumption (151 million cartons) occurs in low smuggling areas, while the remaining 64 million cartons are consumed in high smuggling areas. In high smuggling areas, this 64 million carton total is divided into one third legal ( 21 million) and two thirds contraband (43 million). Legal sales generated $\$ 6.2$ billion in taxes in 1993, divided approximately equally between federal and provincial governments. Using the previous estimate of 
an $18 \%$ increase in consumption in low smuggling areas, sales would rise to 178 million cartons. However at the same time the population-weighted average tax reduction for this area is from $\$ 37.30$ to $\$ 22.10$ (-41\%) per carton. Therefore revenue in low smuggling areas would be reduced from $\$ 5.61$ to $\$ 3.93$ billion, a loss of $\$ 1.69$ billion.

Within the high smuggling areas the scenario is more complicated and depends on the degree of displacement of contraband. From a health point of view the worst case scenario is an expansion of legal sales without displacing contraband, an increase in total consumption, while from a revenue point of view it is immaterial whether the expansion is at the expense of contraband, since the latter generates no revenue. Allen has calculated that, assuming total consumption does not change appreciably, the only way net revenue could increase would be by complete displacement of contraband, and even then the gains would be modest, of the order of $\$ 64.5$ million. The evidence to date does not indicate that contraband has been completely eliminated. Again, examining a range of scenarios would place total revenue losses across the country at between $\$ 1.7$ and $\$ 3.1$ billion.

\section{The balance sheet}

Considering the deficit margins under which governments in Canada are operating, estimates of increased health care costs of $\$ 1.7$ billion, combined with a fall in revenue of another $\$ 1.7$ billion, would aggravate deficits by $\$ 3$ to $\$ 5$ billion depending on the assumptions in the model.

One reviewer has suggested that the true fiscal impact on government needs to take into account the highly controversial theory that there is a net gain to government treasuries from a product that causes premature death, thereby saving society the costs of caring for nonproductive members in their later years, assuming that death and retirement are closely linked (36).

\section{ANALYSIS}

The Federal government was presented with many alternatives to tax reductions, as potential solutions. One proposal contained 44 separate recommendations (37), nearly all of which were revenue neutral or revenue enhancing. Many of these were seen as being necessary on only a temporary basis, in anticipation of sharp rises in US taxation $(38,39)$. The government chose the worst of all possible courses, losing the battles for both death and taxes.

\section{Beyond frontiers - ripple effects and transnationals}

When arguing economics, particularly when recommending to legislators that it would be unwise to reduce smoking, the tobacco industry frequently refers to what is known as the 'ripple effect' (40), whereby every sector of the economy is so interlinked that it is claimed that perturbing one sector will cause a ripple that will effect every other sector. This is the central core of the industry's arguments about why tobacco is essential to the economic health of a community. Warner (40) has demonstrated the fallacy of this viewpoint, resources saved because of reduction in spending on one commodity, being merely diverted into spending on other commodities.

A better example of a ripple effect is the way that industry victories are immediately put to use in every corner of the globe. The world tobacco market is dominated by six transnational companies (41), thus it is not surprising that the industry's success in removing the taxation barrier to consumption in Canada should immediately turn up in industry presentations in the United States (39) or in Africa (D Sweanor, personal communication), where the success of the Canadian taxation story had been central to public health programs.

\section{Early estimates of the damage}

In view of the fact that tobacco sales are reported at the wholesale level rather than retail, and that it is also likely to take some time between tobacco being exported and turning up in the domestic black market, there is likely to be quite a lag period between changes in policy and reported data changes. At the time of writing, data were available up to and including April 1994. However, there have actually been a series of federal and provincial taxation adjustments between February 8 and April 13.

What is apparent is that the manufacturers appear to be anticipating a large increase in consumption since production increased by 1.5 billion (12\%) over the comparable period in 1993, the highest level since 1988. Domestic sales have actually increased by 3.1 billion so far $(41 \%)$, the highest since 1990. While at first glance a reduction in exports of 4.6 billion $(79 \%)$ compared with 1993 , suggests that the policy is working, these levels are still very high, and comparable to 1992 data, implying that smuggling is still very active, although there has been some displacement. It is probably still too early to ascertain just how much consumption will be affected, and national figures hide important regional differences. There are no data on the effect on prevalence.

\section{Modifying influences}

If nothing else, the changes over the past few months have focused public, media and government attention on the issues of tobacco consumption and its overall effect on society and the economy in ways that have not been seen before. This has created a climate that is ripe for suggestions on alternate strategies. While it is difficult to conceive of any single strategy that would have a similar influence on consumption than price, it is likely that a string of events has been set in motion that will eventually dampen the predicted increases. The effects of the taxation changes have already facilitated the legislative passage of provincial tobacco control measures and focused attention on regulating packaging as a legitimate strategy.

\section{CONCLUSIONS}

A new Federal government, which had admittedly inherited a major problem neglected by its predecessor, faced major political pressure to reform a law and order problem in Quebec, eastern Ontario and parts of New Brunswick. The issue had added cogency from the deleterious leakage of 
revenue from taxation in the legitimate market. The government was presented with a wide range of options, which addressed the roots of the problem, namely law and order and control of what was clearly an illegitimate export trade. Instead it decided to ignore the health community and adopt what it perceived as a populist cause, a general aversion to a taxation burden.

As a result the government has inadvertently pushed tobacco control to prominence on the national agenda, worsened the economic situation and angered a large part of the population, without eliminating the problem it most directly addressed.

\section{REFERENCES}

1. Franklin B. Letter to Jean-Baptiste Le Roy, November 13, 1789.

2. Lamont N. Budget Speech, House of Commons, United Kingdom, March 10, 1992, London: HMSO.

3. Huber GL. Tobacco: its history, economics and political influence. Semin Respir Med 1989;10:278-96.

4. Statutes of Canada 31 Vict c 8.

5. Statutes of the Province of Upper Canada 1864 27-28 Vict c 3.

6. Statutes of Ontario 1965 c 130.

7. MacKenzie TD, Bartecchi CE, Schrier RW. The human costs of tobacco use. N Engl J Med 1994;330:907-12,975-80.

8. Goodyear MD. Economic aspects of tobacco usage in Ontario. Report to the Tobacco Strategy, Health Promotion Branch, Ontario Ministry of Health, March 1993.

9. Ontario Fair Tax Commission. Discussion paper: searching for faimess, 1993.

10. Wilson M. Budget Speech, House of Commons, February 26, 1991.

11. Laughren F. Budget Speech, Legislative Assembly of Ontario, April 29, 1991.

12. Jacobs P. Budget Speech, Legislative Council of Hong Kong, March 61991.

13. Lamont N. Budget Speech, House of Commons, UK March 10 1992, London: HMSO.

14. Fisher P. Taxes in the United States. World Smoking \& Health 1994;19:11.

15. Market, demand and elasticity. In: Baumol WJ, Blinder AS, Scarth WM. Economics: Principles and Policy, 2nd edn. Toronto: Harcourt Brace Jovanovich, 1988:431-51.

16. Economics of tobacco consumption in the Americas. In: US Department of Health and Human Services. Smoking and Health in the Americas. Atlanta: US Department of Health and Human Services, Public Health Service, Centers for Disease Control, National Center for Chronic Disease Prevention and Health Promotion, Office on Smoking and Health, 1992; DHHS Publication No (CDC) 92-8419:129-31.

17. Lewit EM, Coate D, Grossman M. The effects of government regulation on teenage smoking. J Law Econ 1981;24:545-69.

18. Lewit EM, Coate D. The potential for using excise taxes to reduce smoking. J Health Econ 1982;1:121-45.

19. Becker GS, Grossman M, Murphy KM. An empirical analysis of cigarette addiction. National Bureau of Economic Research, Working Paper No. 3322. Cambridge: National Bureau of Economic Research, April 1990.

20. Economics of tobacco consumption in the Americas. In: US Department of Health and Human Services. Smoking and Health in the Americas. Atlanta: US Department of Health and Human Services, Public Health Service, Centers for Disease Control, National Center for Chronic Disease Prevention and Health Promotion, Office on Smoking and Health, 1992;
All the models predict significant changes in consumption to emerge, but the Federal health department seems to have no contingency plans to assess the impact. Have we then chosen death over taxes? If so we are likely to reap a harvest of ashes.

ACKNOWLEDGEMENTS: The Non-Smokers' Rights Association provided valuable data on global taxation. Librarians at the Hamilton Regional Cancer Centre, McMaster University and Statistics Canada provided access to much of the documentation, and the reviewers provided much helpful advice.

DHHS Publication No (CDC) 92-8419:131-3.

21. Warner KE. Smoking and health implications of a change in the federal cigarette excise tax. JAMA 1986;255:1028-32.

22. Harris JE. The 1983 increase in the federal cigarette excise tax. In: Summers LH, ed. Tax Policy and the Economy, Volume 1. Cambridge: MIT Press, 1987.

23. US Department of Health and Human Services. The Health Consequences of Smoking: Cancer. US Department of Health and Human Services, Public Health Service, Office on Smoking and Health, 1982; DHHS Publication No (PHS) 82-50179:39-42.

24. Goodyear M. A comprehensive tobacco strategy for Ontario. Report to the Tobacco Strategy, Health Promotion Branch, Ontario Ministry of Health, March 1993.

25. Statistics Canada. Production and Disposition of Tobacco Products. Catalogue 32-022.

26. Freeman A. Imasco can't afford 'nice' role: losses in anti-smuggling stance lead to marketing deal with US rival. The Globe and Mail 1993;May 6:B1.

27. Pack of Trouble. Maclean's 1994;February 21:10-3.

28. Statutes of Canada 1993 c 5.

29. Revised Statutes of Canada 1985 c T-12.

30. The Worst Fear. Maclean's 1994;February 21:14-6.

31. Gray $\mathrm{C}$. The tobacco-tax roll back may end the smuggling, but what will it do to our health? Can Med Assoc J 1994;150:1295-6.

32. Canadian Oncology Society. Health implications of fiscal policy: policy recommendations for the 1992 federal budget. Submission to Finance Canada, February 1992.

33. Allan RC. The false dilemma: the impact of tobacco control policies on employment in Canada. National Campaign for Action on Tobacco, Ottawa, Ontario, 1993.

34. Laughren F. Ontario forced to lower cigarette tax in wake of federal move. Press release, Ontario Ministry of Finance, February 21, 1994.

35. Boudreau B, cited in Cox K. Nova Scotia reluctantly cuts tobacco taxes. The Globe and Mail 1994;April 14:A4.

36. Raynauld A, Vidal JP. Smokers' burden on society: myth and reality in Canada. Can Public Policy 1992;18:300-17.

37. Canadian Cancer Society. Protecting health and revenue: an action plan to control contraband and tax-exempt tobacco. Submission to Finance Canada, January 1994.

38. The US push to raise taxes. Maclean's 1994;February 21:16.

39. Farley CJ. The butt stops here. Time 1994;April 18:44-8.

40. Warner KE. What tobacco contributes to the economy. World Smoking \& Health 1990;3:3-5.

41. World Health Organization. The tobacco industry: strategies and prospects. Tobacco Alert (Special issue: World No-Tobacco Day) 1994:6-8. 


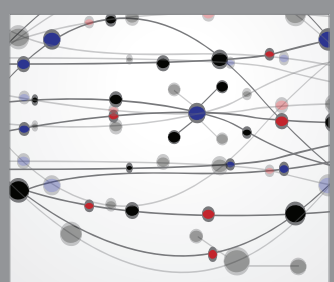

The Scientific World Journal
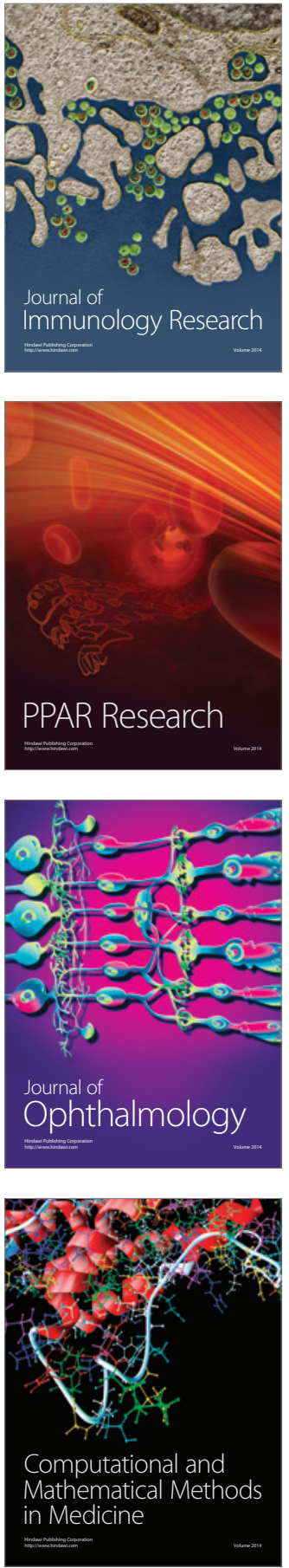

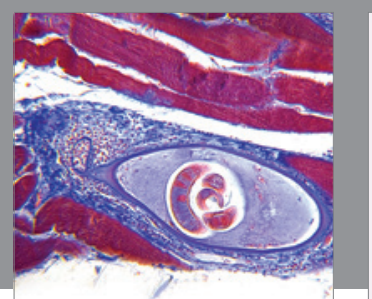

Gastroenterology Research and Practice

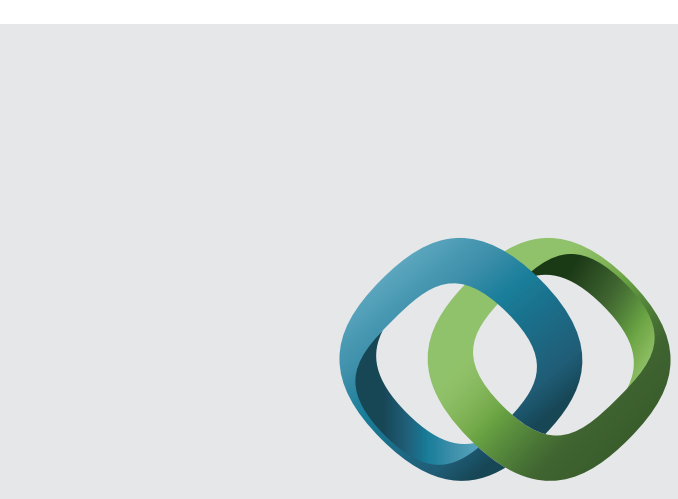

\section{Hindawi}

Submit your manuscripts at

http://www.hindawi.com
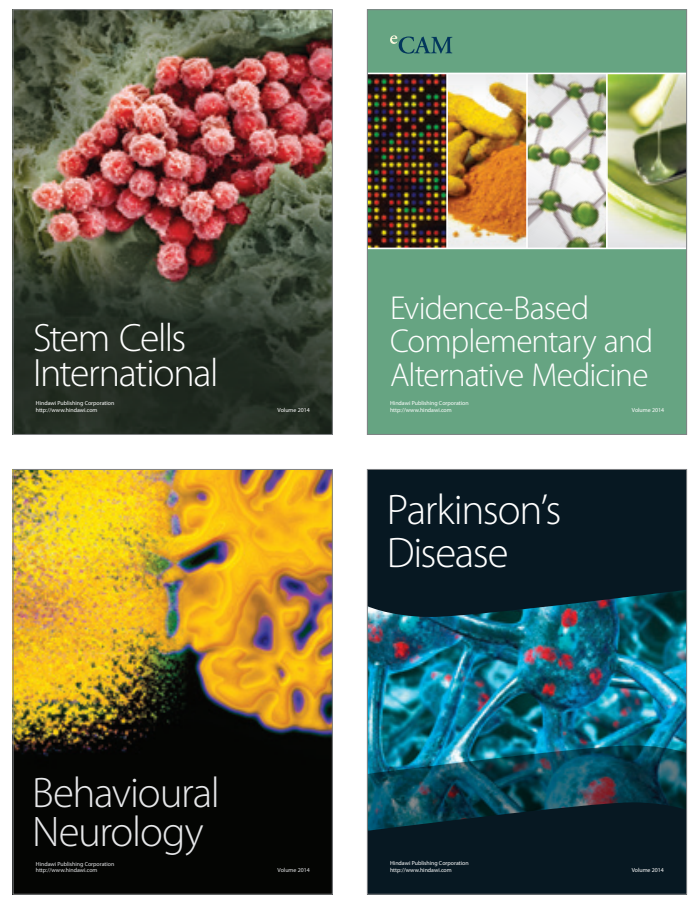
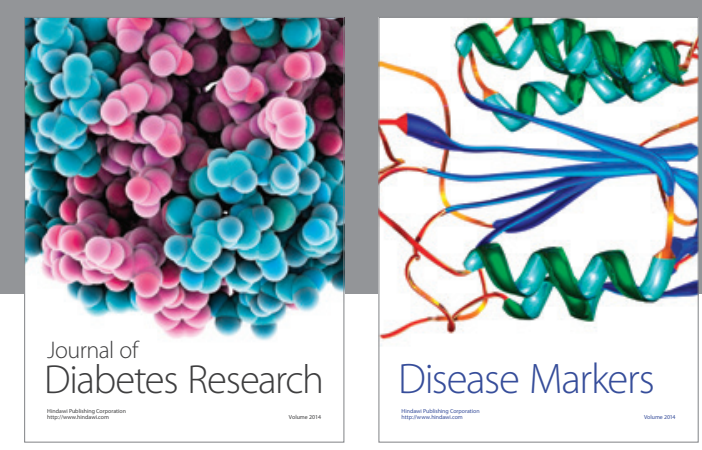

Disease Markers
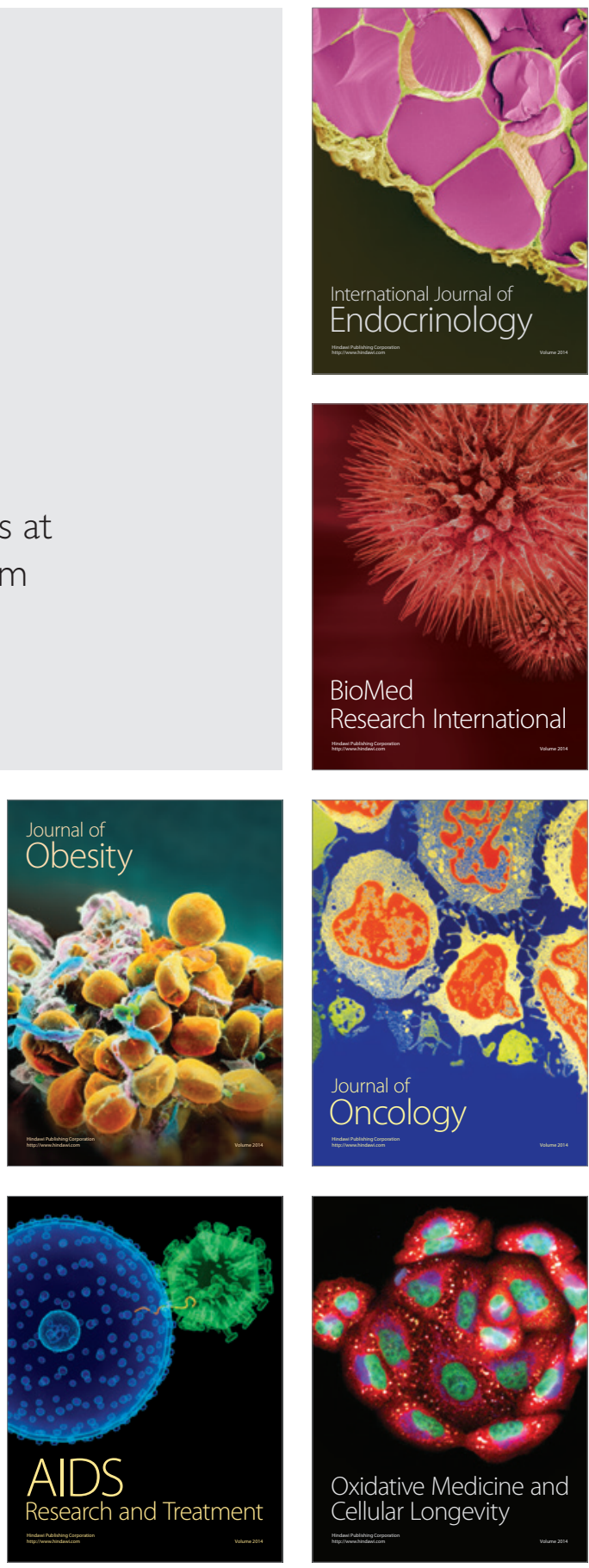